\title{
RECONCILING O-D FREIGHT FLOW DATA AND INTERREGIONAL I-O/MULTI- REGIONAL SAM DATA FOR SCGE DATABASE IN A DEVELOPING COUNTRY*
}

\author{
by Cristela Goce-DAKILA ** \& Shoshi MIZOKAMI ${ }^{* *}$
}

\section{Introduction}

The creation of a database for a spatial computable equilibrium (SCGE) model for a developing country like the Philippines is considered a bold undertaking due to the scarcity of available data. This study attempts to provide a fresh perspective on reconciling available secondary data and collected primary survey data for the compilation of a database for SCGE modeling with a transport sector in the Philippines. It presents a comparative analysis of two datasets: (1) origin-destination (O-D) tables from the 2004 Interregional Freight \& Passenger Flow Survey of Japan International Cooperation Agency (JICA) and the Philippines Department of Transportation \& Communication (DOTC), and (2) interregional input-output (I-O) table from the five-region social accounting matrix in the Philippines constructed by the authors. It will draw from the databases' respective strengths for the construction of a reliable database, which is the basis of a spatial computable general equilibrium model (SCGE) of the Philippines.

There are similarities between commodity flow data contained in origin-destination (O-D) matrices and goods flow data embedded in interregional input-output (I-O) matrix, which is a subcomponent of the multiregional social accounting matrix (MRSAM). Whereas, I-O matrix captures the movement of goods from producer to consumer, O-D matrix depicts the flow of commodities from place of production to place of disembarkation. Hence, all the transaction costs, which include transport costs, mark-up margin, and distribution costs, are not considered in O-D matrix. Transport planning studies typically use O-D matrix to estimate the effects of transport sector on logistic structure and distribution channel of goods. On the other hand, interregional I-O data can be used to establish the pattern of trade from the initial producer to the final consumer. Connecting the two datasets would enable both transport and economic planners to measure the impact of trends in logistics and the economy due to some policy changes. While both datasets have a passenger flow component, this paper will limit itself to commodity flow component.

\section{Scope \& Limitations of the Study}

The limit to reconciliation and revalidation efforts is defined by the ultimate objective of the creation of multi-region SAM. The improved database which will result from the methodology suggested in this exercise will be used to validate an SCGE model for the Philippines. The primary objective of SCGE modeling in this research is to assess the regional impact of transport infrastructure investment on macroeconomic variables, and interregional flows. Such results will be correlated with important social concerns like impedance in mobility, accessibility, regional distribution of welfare and environmental effect. It is widely recognized that simple SCGEs are not forecasting tools by themselves. They have no time dimension and do not allow for forecasted policy interventions over time. (Gunn: 2004) Standard forecasting models and SCGEs are complements because the SCGEs enrich the forecasting dimension by adding new behavioral responses to new price structures brought about by an exogenous shock. In their simplest form, SCGE models stand for a new pattern of production and consumption which will occur if households and firms strive to get to get back to an optimal position subject to their respective constraints.

The baseline data used to validate the model is a multi-region social accounting matrix (MRSAM,). MRSAM represents transactions in a complete economic system subdivided into regions, during an accounting period. It is used to trace economic linkages between producing units and consuming units distinguished by their location. It represents an equilibrium position wherein producers and consumers are

\footnotetext{
* Keywords :commodity flow, origin-destination table, interregional flow, multi-regional social accounting matrix

** JSPS Ronpaku Fellow, M.A. Economics, Dept. of Economics, Associate Professor of Economics, De La Salle Univ. (2401 Taft Avenue, Manila 1004, Philippines, FAX: (632 )-303-0867, email : dakilac@dlsu.edu.ph)

*** Member of JSCE, Dr. Eng., Dept of Civil \& Environmental Eng., Professor of Eng., Kumamoto University

(2-39-1 Kurokami, Kumamoto 860-8555 Japan, FAX: +81-96-342-3541; email : smizo@gpo.kumamoto-u.ac.jp)
} 
maximizing their objectives within certain constraints .To complete the spatial dimension, a transport sector is made explicit together with a government sector and a capital accumulation sector.

There is no official regional social accounting matrix in the Philippines, Because of this; the construction of a comprehensive and reliable database for aforementioned modeling exercise becomes top priority. Due to the tremendous costs in terms of time, computer work, data gathering and surveying, available secondary data were collected and put together to fill in the different components of a MRSAM. These were reconciled with primary data collected by the JICA-DOTC team to reinforce the matrix's integrity. Among these data requirements are (1) a five-region interregional input-output table with compatible dimension as those of the model; (2) international trade and interregional trade data; (3) household income and expenditure data classified by regions; (4) gross regional domestic product and expenditures data; (5) Census of Establishments data; (6) national input-output data, (7) commodity flow data by water and air, (8) Family Income \& Expenditure data. These data sets were reconciled with the aforementioned datasets to complete the MRSAM. There was no O-D data used due to limitations which will be discussed later . Regionalization of national variables utilized non-survey methods like simple location quotient method.

The value-added of this paper is therefore to put side by side the results of secondary data (I-O data) and primary data (JICA-DOTC road interview survey data) so that the figures used in SCGE simulation earn a higher degree of confidence. Differences and similarities in data outcome will be explored. At the very least, the direction and magnitude of freight flow in primary and secondary data sources should be consistent with each other. If there is a difference, a theoretically acceptable explanation will be explored. Furthermore, the contribution of this study is making data used in transport planning and economic impact analysis compatible with each other when expressed in monetary terms. In this case, regional and income accounts will be used.

It is hoped that the validation and reconciliation techniques embodied in this paper will pave the way for exploring potential complementarity between input-output data and origin-destination data of freight flow especially for developing countries where research funds are limited. The section on issues in reconciling these two sources pinpoints key issues which need to be resolved in MRSAM construction .They affect the empirical results derived from the model.

\section{Survey of Current SCGE Models}

A quick survey of SCGE models across the world indicates that a comprehensive and reliable database is imperative to appreciate the full worth of the model. However, a majority of these models come from the developed world like Europe and Japan. They use extensive and recent primary and secondary databases. Specifically, the case of SCGE model of Netherlands, (RAEM), Denmark (BROBISSE) and Europe (CGEurope) have a wide database from which SCGE model can be validated. Other SCGE models in developed countries which have been completed and which used an extensive transport, socio-economic and demographic database are PINGO in Norway, MH model in Japan, Hewings, Kim and Haddad model for South Korea. These include demographic data like migration and other socio-economic data. In the case of CGEurope, Brocker uses an 800 region model. They use official regional SAM data, transport satellite accounts and commodity flow survey. In the Philippines, where substantial amount of foreign funding goes into transport infrastructure investment, only the last database is available but with accounting limitations which will be discussed in later section.

Since this is an initial attempt at SCGE modeling and multi-region SAM construction in the Philippines; effort was exerted in utilizing existing secondary data using non-survey regionalization techniques and recently finished primary data to create an improved database for the first SCGE model for the Philippines. It must be noted that interregional flows in PIRIO were estimated using non-survey techniques and secondary data from government statistical agencies and were not based on origin-destination flow surveys. The JICADOTC survey was conducted at a later date than creation of PIRIO. Hence this study explores complementarities between PIRIO and JICA-DOTC survey so that a robust database is created. This paper documents the efforts exerted to put spatial dimension in officially available statistics and to reconcile secondary with primary data.

\section{Objectives and Methodology of JICA-DOTC O-D Survey}

\section{(1) Objectives of JICA-DOTC O-D Survey}

The primary objective of the JICA-DOTC study is to provide a common socio-economic and transport information database for planning in each of the transport sub-sectors namely road, rail, water and air 


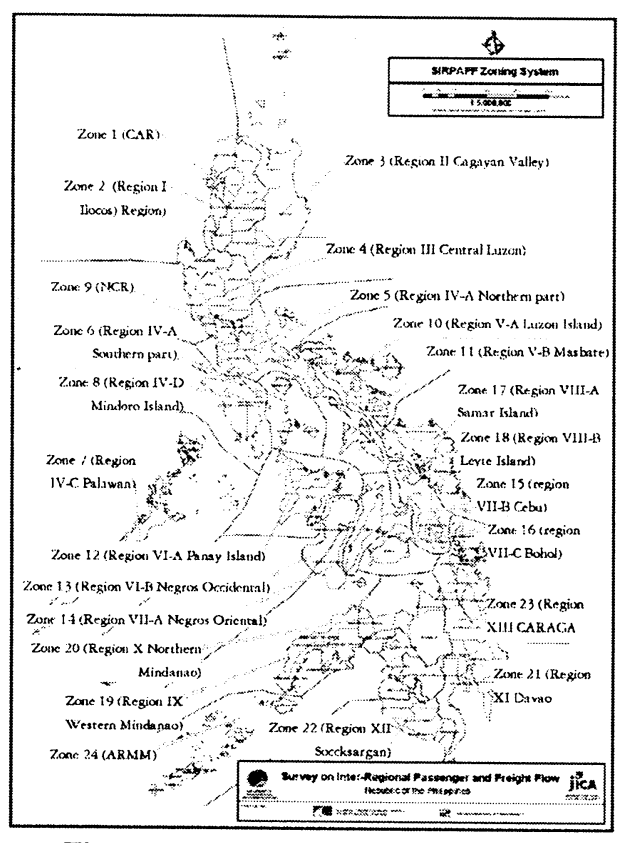

Figure 1: JICA-DOTC zoning system transport. However, the particular objectives include the following: (1) Formulate the list of existing transportation routes for various modes of both passenger and freight inter-regional and intra-regional flows; (2) Formulate inter-regional transportation passenger and freight matrices by route and transportation modes; and (3) Conduct technology transfer to the counterpart personnel in government agencies. (2004: JICA- DOTC Study)

\section{(2) Methodology of JICA-DOTC O-D Survey}

O-D tables were estimated for commodity flow per transport mode. Originally, interspatial flows across the Philippines were traced among 24 zones, which were then compressed into 11 islands and finally into 5 regions which are compatible with areal disaggregation of MRSAM, as enumerated in Table 1 and shown in Figure 1. Freight flow O-D tables were estimated for the following transport modes - road, rail, water and air. Freight flow via air, water and rail were derived from secondary sources, namely, 2002 commodity flow and trade statistics of the National Statistics Office (NSO). However, primary data for freight flows via road were taken from roadside interviews of drivers, freight carriers, representative bus operators and large corporations with their own freight distribution.

Table 1: JICA-DOTC O-D Survey Zoning System

\begin{tabular}{|c|c|c|c|c|}
\hline \multirow{2}{*}{$\begin{array}{ll}\text { Zone \& Region } & \text { CAR Cordillera Admin. Region }\end{array}$} & \multicolumn{2}{|c|}{11 Major Islands } & \multicolumn{2}{|c|}{ Five Greater Regions } \\
\hline & 1 & Luzon & 1 & Northern Luzon \\
\hline 2 Region1 llocos Region & 1 & Luzon & 1 & Northern Luzon \\
\hline 3 Region 2 Cagayan Valley & 1 & Luzon & 1 & Northern Luzon \\
\hline 4 Region 3 Central Luzon & 1 & Luzon & 1 & Northern Luzon \\
\hline 5 Region IV-A Southern Tagalog & 1 & Luzon & 3 & Southern Luzon \\
\hline 6 Region IV-B Southern Tagalog & 1 & Luzon & 3 & Southern Luzon \\
\hline 7 Region IV-C (Palawan) Southern Tagalog & 2 & Palawan & 3 & Southern Luzon \\
\hline 8 Region IV-D (Mindoro) Southern Tagalog & 3 & Mindoro & 3 & Southern Luzon \\
\hline 9 NCR National Capital Region & 1 & Luzon & 2 & NCR \\
\hline 10 Region V-A (Luzon) Bicol & 1 & Luzon & 3 & Southern Luzon \\
\hline 11 Region V-B (Masbate) Bicol & 4 & Masbate & 4 & Southern Luzon \\
\hline 12 Region VI-A (Panay Island)Western Visayas & 5 & Panay & 4 & Visayas \\
\hline 13 Region VI-B (Negros Occidental) Western Vis. & 6 & Negros & 4 & Visayas \\
\hline 14 Region VII-A(Negros Oriental)Central Visayas & 6 & Negros & 4 & Visayas \\
\hline 15 Region VII-B (Cebu ) Central Visayas & 7 & Cebu & 4 & Visayas \\
\hline 16 Region VII-C (Bohol) Central Visayas & 8 & Bohol & 4 & Visayas \\
\hline 17 Region VIII-A(Samar Island ) Eastern Visayas & 9 & Samar & 4 & Visayas \\
\hline 18 Region VIII-B (Leyte Island) Eastern Visayas & 10 & Leyte & 4 & Visayas \\
\hline 19 Region IX Western Mindanao & 11 & Mindanao & 5 & Mindanao \\
\hline 20 Region X Northern Mindanao & 11 & Mindanao & 5 & Mindanao \\
\hline 21 Region XI Southern Mindanao & 11 & Mindanao & 5 & Mindanao \\
\hline 22 Region XII Central Mindanao & 11 & Mindanao & 5 & Mindanao \\
\hline 23 Region XIII(CARAGA) & 11 & Mindanao & 5 & Mindanao \\
\hline 24 ARMM & 11 & Mindanao & 5 & Mindanao \\
\hline
\end{tabular}

Table 2: Number of Survey Site Stations in JICA-DOTC O-D Survey

\begin{tabular}{|l|c|}
\hline \multicolumn{1}{|c|}{ Region } & $\begin{array}{c}\text { Number of Survey } \\
\text { Site Stations }\end{array}$ \\
\hline Northern Luzon & 10 \\
\hline National Capital Region & 0 \\
\hline Southern Luzon & 6 \\
\hline Visayas & 12 \\
\hline Mindanao & 9 \\
\hline
\end{tabular}

For freight flow data, the JICA-DOTC Survey aimed to establish the volume of commodity flows in terms of number of trips and weight of each commodity type transported by all modes on an annual basis. In the case of freight flow via road, the number of freight trips captured on daily basis was expanded to a typical week OD. This was later expanded to an integrated annual OD data. Commodity flows were expressed in terms of average 
weight per commodity type and vehicle type. Annual totals in terms of commodity flows via air, water and rail were taken from commodity flow data of the NSO. As stated previously, there were three zoning system used for areal disaggregation, namely: 24 zones, then 11 islands and then 5 regions. The latter 5 regions corresponded to the same five regions used in the multi-regional SAM. The distribution of roadside survey locations (Table 2) was based the existence of major trunk roads forming the national trunk road network. (JICADOTC Survey: 2004, pp.3-7, 6-12)

Data gathering for commodity flow was vehiclebased. Freight trips were classified into three main vehicle classes, namely small (jeepney, vans or pick-ups), medium (2-axle trucks) and large-sized trucks. For each of these vehicle types, average weights per commodity type were extracted from the freight survey data. The calculation of average weight per commodity carried by each vehicle type involved classifying the commodity carried by each vehicle type according to the 12 commodity types (JICA-DOTC Study: 2004). ${ }^{1}$

\section{Objectives and Methodology of Construction of Five-Region SAM}

\section{(1) Objectives of Five-Region SAM}

The main purpose of constructing the multiregional SAM is to provide the database that will be used as benchmark in deriving equilibrium values of spatial computable general equilibrium model. The conceptual and accounting framework is designed based on the closed type of multiregional SAM model, wherein the household sector is treated as endogenous within the production system. Furthermore, the model attempts to decompose the household sector into income groupings-low, middle and high-income group-to give clearer picture of welfare effects across economic groups.

\section{(2) Methodology of Construction of Five-Region SAM}

\section{a) Scope and Coverage}

The 15 administrative regions of the country in 1994 (now 17) are regrouped into five greater regions following the geographic delineation used in compiling the 1994 5-region Philippine Inter-Regional I-O table (PIRIO), which is the principal data source for this study. The regional groupings are shown in Table 3 . In this closed MRSAM model, (7) major industry divisions and three (3) income groups of households comprise the production sector. ${ }^{2}$

\section{b) Methodology of Five-Region SAM (MRSAM) Construction - Three Major Activities}

There were three major activities undertaken to derive the MRSAM. These were carried out in the following order: (1) expanding the Scope and Coverage of the 1994 Open-Type PIRIO Model, (2) closing the Expanded PIRIO Table and (3) compiling the MRSAM.

Phase 1: Expanding the 1994 Interregional (IRIO) Model of the Open-Type (See Figure 2)

The construction of five-region SAM involved expanding the scope and coverage of the 1994 five-region PIRIO model, to support the data needs of the accounting framework of the MRSAM model. The three

\footnotetext{
${ }^{1}$ The commodity classifications are: (1) unprocessed cereals, (2) agricultural food stuffs, (3) agricultural cash crops, (4) processed cash crops, (5) cereal product, (6) manufactured food stuff, (7) other manufactured goods, (8) forestry products, (9) mining products, (10) mineral oil products, (11) construction materials and (12) producer goods.

${ }^{2}$ The components of MRSAM sectors are: (1) Agriculture-crops, fishery, forestry, livestock \& poultry, (2) Industry-construction, mining, manufacturing, electricity, gas \& water, (3) Other Services- Private Services, Finance, Insurance \& Real Estate, Trade, (4)Water Transport Services, (5) Air Transport Services, (6) Land Transport Services, (7)Government Services, (8) Low Income Household Group (families with annual income below regional poverty threshold), (9) Middle Income Household Group, (10) High Income Household Group (families with annual income above 250,000 pesos).
} 
sectors which require further refinements are as follows: (1) Private Consumption Expenditure Sector of Final Demand (PCE), (2) Operating Surplus (OS) and (3) Rest of the World (ROW).

Table 3: Regional Composition of Five Delineated SAM Regions

\begin{tabular}{|l|l|}
\hline \multicolumn{1}{|c|}{ MRSAM Region } & \multicolumn{1}{c|}{ Administrative Region composition } \\
\hline Northern Luzon & $\begin{array}{l}\text { Cordillera Administrative Region, Ilocos Region, Cagayan Valley, } \\
\text { Central Luzon }\end{array}$ \\
\hline National Capital Region & National Capital Region \\
\hline Southern Luzon & Southern Tagalog, Bicol Region \\
\hline Visayas & Western Visayas, Central Visayas \& Eastern Visayas \\
\hline Mindanao & $\begin{array}{l}\text { Western Mindanao, Northern Mindanao, Southern Mindanao, Central Mindanao, CARAGA } \\
\text { and Autonomous Region of Muslim Mindanao }\end{array}$ \\
\hline
\end{tabular}

The first refinement concerns the PCE item. This item, which is a column vector of final demand, shows expenditures by households, including non-profit institutions serving households (NPISH). While it is ideal to separate these two categories as sub-vectors of PCE, the expenditure data for NPISH is included in overall PCE. This is because PCE of NPISH covered only a mere $5 \%$ of total PCE in 1994. The regional PCE in five regions IRIO is then further decomposed into the three sub-vectors which represent the three pre-determined household income classes -low income households, middleincome households and high-income households.

The take-off point in delineating the three sub-groups is the low-income group, given

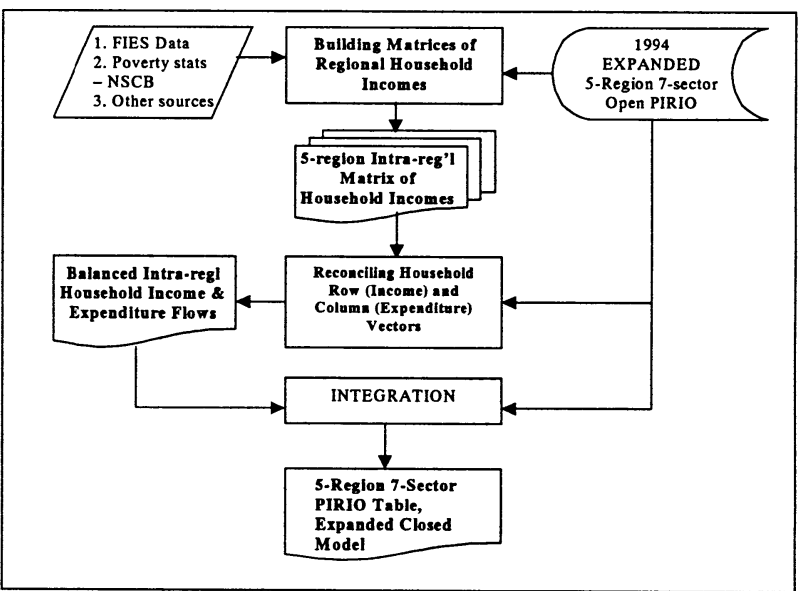

Figure 3: Closing the IRIO Model by Endogenizing the Household Sector -Phase 2 FIES and poverty thresholds data. In this study, low-income households are defined as those with incomes falling below poverty lines, based on poverty thresholds at the regional level. Families across all regions with 1994 annual income of at least $\mathrm{P} 250,000$ or P20,000 per month were taken to belong to the high-income group. Families in income class brackets between the upper income bracket and the low-income group constitute the middle-income group. Estimation of final consumption expenditures for each of these three household groups, as sub-sectors of final demand, then follows using FIES data on expenditure patterns by income class with the recorded figures in the PIRIO table serving as the control totals.

The second refinement in expanding the five-region PIRIO is to decompose the operating surplus or other value-added (OVA) component of GVA into: (1) net land rent, (2) net interest payments, (3) domestic/foreign dividends /transfers; (4) direct taxes and (5) the residual which is the net operating surplus (composed of savings and other value-added). ${ }^{3}$

\footnotetext{
${ }^{3}$ The derivation of each of the sub components of OVA is explained below.

The first subcomponent of OVA is land rent. Data for land rent came from the 1994 Census of Establishments (CE) for the non-agricultural sector and private services sector. For the agricultural sector, land rent estimates were derived from regional cost-and-returns survey data of the Bureau of Agricultural Statistics (BAS), Philippine Department of Agriculture. Due to data limitations, it is assumed that income from land rent in the transport sectors is negligible; hence no estimate was made. The same goes for the government services sector because available financial reports are too consolidated to be able to estimate land rental incomes.
}

The second subcomponent of OVA is net interest payment. It is calculated as interest expense less interest income. The 1994 CE results provided the data for the industry and private services sectors, while BAS cost-and-returns survey on selected agricultural products served as the basis for the agriculture \& forestry sector. Interest payments by the government sector have not been recorded due to data lack.

The third subcomponent of OVA is dividends and transfers. Firms' dividends include dividends on investment made by households and by foreign investors (ROW). Dividends to households were estimated at the regional level using FIES data as indicators with given national official figure from DOF statistics as control total. Regional estimates on dividends to the ROW were obtained by prorating given DOF's recorded national total using regional output shares as indicators. Transfers refer to grants-in-aid to households from government and remittances to households from ROW. It 
The third and last refinement of PIRIO to convert it to MRSAM is with regards to breakdown of imports from ROW. The MRSAM framework requires the breakdown of import transactions recorded in the IRIO table into (a) CIF values and (b) estimated tariffs \& import taxes. The tax component of imports is then accounted for as receipt of government in the IRSAM. In the absence of hard data on import tax payments by using sector, estimated regional import tax receipts by commodity group were allocated to each using sector in

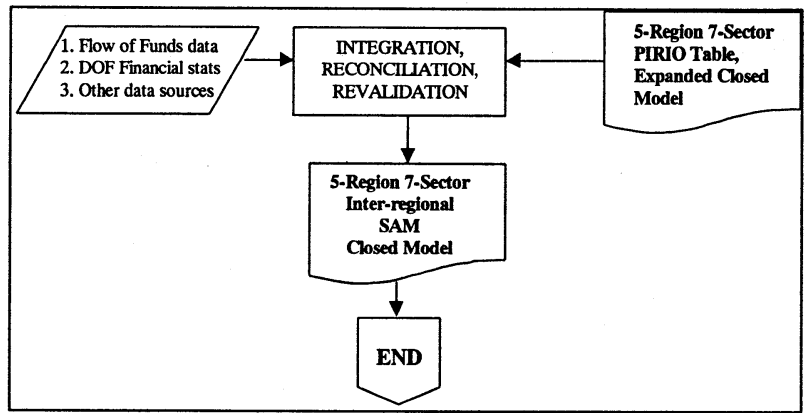

Figure 4: Building the Five-Region SAM - Phase 3 proportion to producers' price values of imports as reported in the IRIO table. That is,

$$
\operatorname{MTAX}_{i j}^{R}=\mathrm{M}_{i j}^{R} / \mathrm{TM}_{i}^{R} * \mathrm{TMTAX}_{i}^{R}
$$

Where: $\operatorname{MTAX}_{i j}{ }^{R}$ is estimated tariff \& import tax of commodity $i$ consumed by using sector $j$ in region $R$; $\mathrm{M}_{i j}{ }^{R}$ is producers' price value of imports of commodity $i$ consumed by sector $j$ in region $\mathrm{R} ; \mathrm{TM}_{i}^{R}$ is total imports of commodity $i$ in region $R$; and TMTAX ${ }_{i}^{R}$ is estimated total import tax revenue for commodity $i$ in region $R$.

In the case of net land rent for the agricultural sector; land rent estimates were derived from regional cost and returns survey data from the Bureau of Agricultural Statistics (BAS), Dept. of Agriculture. For the nonagricultural sector; and private services, land rent data were derived from the 1994 Census on Establishments. The second component of operating surplus is net interest payment and is computed by subtracting interest income from interest expense. The data on transfers and direct taxes are taken from 1994 Family Income \& Expenditure Survey. Then imports from rest-of-the world are broken down into (1) C.I. F. values and (2) estimated tariff and import taxes.

Phase 2: Endogenizing the Household Sector to Close the Expanded PIRIO Table (See Figure 3)

The PIRIO is transformed from open-type IO model to a closed-type of IO model by endogenizing the household sector within the production system of regional economies. The column vector of households in final demand column is transferred as row vector of the same number of households in the intermediate input section of the PIRIO.

Entries along each household row accounts for household incomes derived from three main sources, namely: 1) salaries \& wages, 2) entrepreneurship, and 3) transfers whether domestic or foreign. The household column entries record household expenditures for goods and services plus direct and indirect taxes paid to government and estimated household savings. Thus, in this closed-type IRIO table, household row totals that account for total household incomes are equal to household column totals that account for total household expenditures. The closed-type IRIO table is thus a balanced matrix of inter-regional, inter-industry transactions of goods and services, with the household sector treated as a production sector.

The Philippine FIES serves as the primary source of data on household income and expenditure of families by income class and by region. Satellite tables were created to record household incomes derived from economic activities and institutions. There are 3 primary sources of income namely - (1) salaries and wages; (2) income from entrepreneurial activity and (3) transfer income. The decomposition of households by income class and by region is delineated in the satellite tables.

also includes operating surplus derived from entrepreneurial household-operated economic activities. DOF data provided the national control totals, further decomposed into regional levels using FIES indictors.

The fourth subcomponent is that of direct taxes and net operating surplus. The Annual Report of Department of Finance 's (DOF) national figure of total direct taxes generated from industries was broken down into regional levels using output shares obtained from the $1994 \mathrm{I}$-O table. Total direct income taxes paid by households, as reported in DOF statistics, was regionalized using FIES indicators. The DOF statistics were taken from its annual report. It contains data on breakdown of tax revenue by direct tax, indirect tax and tariff revenues. In the case of fifth subcomponent, net operating surplus of firms was derived as residuals between total GVA and the sum of the other components of value added including household income generated from entrepreneurship. Net operating surplus by households refers to household savings. FIES indicators provided the basis in disaggregating savings by region and by household group. 
In the FIES, family expenditure patterns (in percent) are tabulated by expenditure item, by income class and by region. To obtain the required absolute values, the percent shares are multiplied by their corresponding recorded totals for each income class.

Phase 3: Compiling the MRSAM Accounts (See Figure 4)

The final stage of the compilation process is to build the five-region MRSAM, given the expanded PIRIO table that has been modified to suit to the data needs of the chosen MRSAM framework. The result is a five-region, seven-sector MRSAM for 1994, given the extended five-region IRIO table and the satellite table on regional household incomes. (The choice of 1994 as base year is based on the reality that as of this date, the latest official national input-output data for the Philippines is for 1994. The new official national IO was released last May 1, 2006)

Department of Finance Annual Report was source of data for indirect tax, direct tax and tariff revenue. Flow-of-funds data used in MRSAM like savings of government, firms and rest-of-the-world, current account balance, foreign borrowing, net transfers from abroad were taken from Bangko Sentral ng Pilipinas (BSP) publications on balance of payment and flow-of-funds account. The other FOF data were not used since the focus of research is on interregional of flows. The latter is essentially based on multi-region I-O table. These financial data were allocated among the regions using I-O indicators such as gross output. Other sources of data include Census of Establishments, ad hoc IO Survey of Establishments, national IO table and JSPS-Manila IO database.

\section{Issues in Aligning Inter-zonal O-D Data with Interregional I-O Data in MRSAM}

There are conceptual and practical issues involved in delineating freight flow across regions in an archipelago like the Philippines. The first issue involves the conversion of physical units to monetary terms. The objective of the OD data preparation for freight flows is to establish the magnitude of commodity volumes in terms of trips and weight under each commodity type carried by all modes on an annual basis (JICA-DOTC Survey: 2004). OD tables for commodity flows via air, water and rail were taken from National Statistics Office data. NSO annual totals are presented in physical units (metric tons) and monetary value. The usage of secondary NSO data involves tracing commodity flow from 'port-to-port', 'airportairport' or station-to-station. For freight flows via road; primary data came from roadside interviews with randomly selected respondents. Therefore in comparing commodity flows using O-D data from JICA-DOTC survey and from multi-regional SAM I-O data, available conversion factor, which is peso per metric ton in 1994 prices, must be utilized. Eventually, both O-D data and MRSAM I-O data are in peso terms. To do the reverse, which is to convert monetary terms to volume units - metric tons- is not feasible with current state of Philippine data. This is because, economic flow data as depicted in MRSAM when converted to physical terms is a per unit of output data and not per metric ton data. The heterogeneity of per unit of output data requires that per unit data be homogenized into per metric ton data. This distinction magnifies the difference in the notion of "quantity" in transport planning and "quantity" in economic impact studies. This is the disadvantage of expressing commodity flows in volume units rather than monetary units. Also, if monetary valuation of commodity flows is adopted, then the issue of which price should be used - producer price or consumer price - should be resolved.

The second issue is the delineation of spatial units. The disaggregation of areas into zones and eventually into regions was based on island groupings, which were later merged to become regional groupings. Clearly, the use of islands as basis of zoning emphasizes the geography of the Philippines as an archipelago. This would distinctly trace the flow of commodities from port-to-port and airport-to-airport. However, economic ${ }^{4}$ data are filed according to administrative regions of the Philippines and so provincial level totals have to be utilized to realign zonal groupings in JICA-DOTC O-D data with MRSAM I-O data.

The third issue is the classification of sectors. There is a need to realign classification of freight in O-D table with classification of commodities in input-output tables. Philippine input-output tables use Philippine Standard Industrial Classification (PSIC) classification. Freight flow data are mainly categorized into agricultural products, manufactured goods, mining products, construction materials and producer goods. These goods are measured in units of volume. While a detailed disaggregation of the sectors is desirable, difference in emphasis in transport planning and economic research could lead to misalignment of sectors. For example, transport studies will use volume-distance variables whereas economic impact studies measure 
welfare effects in monetary terms. The sectoral disaggregation entails different units of measurement. Clearly a lower level of disaggregation needs to be used to trace interspatial movements of cargo.

The fourth issue concerns the survey methodology used in primary data gathering for O-D data. To meet its objective of measuring commodity flow per transport mode, roadside interviews were vehicle based. Appropriate checks should be instituted to prevent double-counting or understatement of vehicle trips per time period. It is also suggested the transport manifests or bills of lading of firms engaged in road transport of their raw materials be used as basis for control totals of value of goods transported between two points in space.

The fifth issue is the time period of study. There is a ten- year gap between the O-D flows surveyed in JICA-DOTC study (2004) and intraregional and interregional flows estimated in MRSAM (1994). Between 1994 and 2004, vital transport infrastructure investments took place in NCR, which have tremendous impact on patterns of interspatial flows. These include the operation of the Metro Rail Transit in 1998, the opening of Skyway expressway south of Manila; and the opening of Centennial Airport or NAIA 2 in 2000. So while adjustments in price in consideration of inflation and spatial differences can be made, the composition of flows 2004 maybe vastly different from those in 1994.

The sixth issue concerns secondary method used in measuring interregional good flows. There is an extensive literature on the use of trade coefficients, gravity model, entropy model, distance decay function which deal with the problem of measuring interregional good flows. However, due to time and data limitations, the RAS technique and location quotient method were utilized.

The five-region SAM is the final product of pioneering efforts in regional input-output table construction funded by the Japan Society for the Promotion of Science (JSPS) which started with the creation of a single region input-output table for the National Capital Region (NCR). The next step was to create a bi-regional input-output table (NCR vs. the rest-of-the-Philippines). The last step in the JSPS initiative under Dr. Kenji Doi was to create a five-region input output table using the 2-region I-O as take off point. It was at this point that tremendous effort and resources were used by the authors to construct a five-region SAM for SCGE modeling for transport infrastructure investment appraisal in the Philippines. The mother table used for all interregional I-O and the multi-regional SAM was the official national input-output table of the Philippines for 1994.

A note on inadequate trade data for the Philippines follows. There is no direct data on regional exports and imports including domestic trade flows. . While commodity flow statistics are published by the National Statistics Office (NSO), their usefulness as data source for interregional flows is limited when applied to the accounting framework of I-O analysis. (Secretario: 2002). The rigid IO rule is that flows of goods should be depicted from producer to consumer. The flow of commodities via middlemen like wholesalers and retailers are considered as part of the O-D flows but not reflected in NSO data. Other issues like existence of in-transit flows and cross hauling are not taken into consideration in compilation of existing NSO commodity flow data.

It is at this point that some discussion on the derivation of interregional flows in 5-region IRIO be undertaken to fully appreciate the value of this study. From the gross regional domestic expenditures of the National Statistical Coordination Board, net export data were compiled. Foreign export of a commodity was taken from Census of Establishment data. Foreign imports were estimated using the national import content ratios as proxy indicators. This is based on the assumption that regional economies follow that national economy's consumption pattern of imported products, whether for final production or final consumption. Domestic imports were estimated using the simple location quotient (SLQ) method. SLQ ratio is the percentage share of output of industry at the regional level out of total regional output divided by percentage share of output of industry at the national level out of total national output. If the region imports some product from the rest of country, then SLQ is less than unity. These ratios are applied to sectors in the intraregional table (net of foreign imports) for those with SLQs less than one. Those sectors with SLQs greater than or equal to one are assumed to be self-sufficient. Foreign exports were estimated using Census of Establishments Data. Domestic exports are the residual value after foreign exports are subtracted from net exports.

Therefore the, PIRIO does not use O-D data as basis for estimating interregional flow. The interregional flows depicted in PIRIO were the result of non-survey techniques used like simple location quotient. The SLQ is the embodiment of trade coefficient because it gives an indication on whether the sector is an importing sector or is self-sufficient or exporting sector. It adjusts the input coefficient downwards. The difference between the old control totals and the new control totals is placed in the imports row of the noncompetitive IO table. Then readjustment to new control totals is undertaken using RAS technique. 
The interregional trade coefficient on the other hand is the ratio of total imports to domestic demand per sector where imports are derived from an import matrix using SLQ method.

The seventh issue deals with the vastly different objectives of gathering O-D data and I-O data. O-D data are used in transport planning to pinpoint optimal transport routes, to determine optimal points of intermodal transport systems and minimizing transport cost of goods across space. On the other hand, I-O data are mainly used in economic planning to measure inter-industry linkages and spatial spillover effects on major economic variables. Hence the degree to which O-D matrices can be adjusted to capture the entire process of movement of a good from its raw material stage to delivery of final good to the ultimate consumer depends on the primary objective of the research.

The eighth issue deals with the prices. One essential difference between I-O table and O-D table is that the latter is expressed in producer prices whereas the former is expressed in consumer prices. Consumer prices include trade and transport margins in delivering product to the purchaser plus the producer price. It includes the cost of intermediation cost from point of disembarkation to the point of final consumption. On the other hand, producer prices include the basic price received by the producer plus indirect taxes less subsidies on the product.

\section{Procedure for Integrating Primary Data in OD Tables and Secondary Data in SAM}

The previous sections underscored the similarities between O-D and I-O data. Both trace the movement of freight and corresponding factors of production across space. However, certain improvements may be undertaken to link the two tools. This procedure will be explained by using the flowchart shown in Figure 5 .

First, classification of freight in O-D table will be realigned with classification of commodities in inputoutput tables. Philippine input-output tables use Philippines Standard Industrial Classification (PSIC) classification. Secondly, O-D flows which are expressed in terms of volume-distance can be converted into monetary terms, using regional producer price indices for the year when the flows were surveyed. Currently, commodity flows from O-D tables are expressed in producer prices. Thirdly, the zonal classification of origin-destination areas will be converted into administrative disaggregation of regions as filed in Philippines statistical agencies. Fourthly, all commodities transported by different transport mode from different O-D pairs should be added up together to get total commodities transported from one point to the other. Fifthly, since the current official I-O data are in 1994 prices, the monetary I-O data can be converted from 1994 to 2004 prices. Alternatively, monetized volume data of commodity flow in O-D tables can be converted from 2004 to 1994 prices, depending on availability of conversion data. This procedure can be deduced from the figure below:

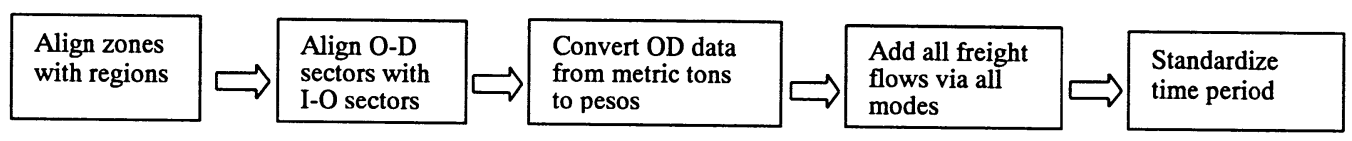

Figure 5: Process of Alignment of O-D and I-O Data

\section{Empirical Results of JICA-DOTC Study \& Multiregional SAM-IRIO Construction}

\section{(1) Results of JICA-DOTC Freight O-D Survey}

A very important finding of JICA-DOTC O-D survey is that around $99.97 \%$ of annual commodity movement was via road. This finding may seem strange considering the fact that the Philippines is an archipelago and most of interspatial movement would be via water. One factor which may have lead to this result is that transport of cargo using inter-modal scheme such as the Ro-Ro (roll-on, roll-off) is classified as transport via road. It would be interesting to look at freight OD tables by all modes. (See Table 4)

Table 4: Freight O-D Flows, All Modes of Transport, in 1994 prices (in Million Pesos) (Based on JICA-DOTC Survey \& Using NSO Water Cargo Mode 1994 Conversion Rate)

\begin{tabular}{|l|c|c|c|c|c|c|}
\hline \multirow{2}{*}{ Origin } & \multicolumn{5}{c|}{ Destination } \\
\cline { 2 - 6 } & NCR & N. Luzon & S. Luzon & Visayas & MIND & TOTAL \\
\hline NCR & 0 & 361,568 & 92,063 & 48,581 & 29,238 \\
\hline N. Luzon & 172,309 & 203,991 & 22,654 & 7,478 & 4,595 \\
\hline S. Luzon & 272,727 & 56,662 & 218,939 & 16,211 & 6,212 & \\
\hline Visayas & 25,286 & 23 & 9,513 & 36,101 & 10,964 & \\
\hline Mindanao & 32,066 & 1,472 & 1,296 & 23,710 & 119,791 & \\
\hline TOTAL & 502,388 & 623,717 & 344,466 & 132,082 & 170,800 & \\
\hline
\end{tabular}


(2) Results of Inter-regional IO-MRSAM Construction

On the other hand, the interregional commodity flow of five-region I-O which is part of the SAM showed the following results. NCR was the top region which received highest monetary value of goods as destination area. Also, Southern Luzon which includes the CALABARZON area was top region as place of origin of goods in 1994. (See Table 5)

Table 5: Commodity Flow Data from Inter-regional Competitive IO Table, 1994 (Million pesos at 1994 producers' prices)

\begin{tabular}{|c|c|c|c|c|c|c|}
\hline \multirow[t]{2}{*}{ Origin } & \multicolumn{6}{|c|}{ Destination } \\
\hline & NCR & N. Luzon & S. Luzon & Visayas & Mindanao & TOTAL \\
\hline NCR & 498,979 & 33,821 & 25,527 & 30,612 & 30,612 & 606,719 \\
\hline N. Luzon & 22,887 & 256,315 & 3,592 & 5,738 & 5,738 & 292,491 \\
\hline S. Luzon & 52,687 & 22,539 & 486,304 & 24,241 & 24,241 & 607,393 \\
\hline Visayas & 23,967 & 7,138 & 5,327 & 195,345 & 195,345 & 236,874 \\
\hline Mindanao & 49,374 & 3,280 & 10,099 & 9,318 & 260,152 & 332,225 \\
\hline TOTAL & 647,896 & 323,094 & 530,852 & 265,256 & 265,256 & $2,075,704$ \\
\hline
\end{tabular}

\section{(3) Comparison of Results in Terms of Magnitude of Freight Flow}

The results, as seen in Table 6 below, as shown by I-O/O-D ratios, indicate that monetary values of commodity flows in interregional input-output (IO) flows are higher than those in O-D tables in all regions except Northern Luzon. All ratios are greater than one except Northern Luzon. (See Table 6 ) This can be attributed to the following reasons :(1) interregional I-O data includes transport costs from point of production to point of disembarkation while O-D includes only monetary value of commodities transported excluding transport margins, profit margins etc and other intermediation costs. (2) The interregional flows from I-O data include monetary value of intangibles like services which are excluded from actual interregional flow of goods in O-D tables. Therefore flows tend to be overstated ; (3) the O-D tables exclude intraregional flow of goods within NCR and have assigned a zero value to NCR-NCR transactions and (4) the concept of "quantity "in expressed differently in freight flows in O-D tables ( metric tons ) as compared to quantity in interregional I-O tables.

Table 6: Ratio of Magnitude of I-O Commodity Flow to O-D Commodity Flow

\begin{tabular}{|c|c|c|c|c|c|c|}
\hline \multirow[t]{2}{*}{ Origin } & \multicolumn{6}{|c|}{ Destination } \\
\hline & NCR & N. Luzon & S. Luzon & Visayas & Mindanao & Avg. IO/OD Ratio \\
\hline NCR & Undefined & 0.0935 & 0.2773 & 0.6301 & 0.6081 & 1.1416 \\
\hline N. Luzon & 0.1328 & 1.2565 & 0.1586 & 0.7674 & 0.8612 & 0.7116 \\
\hline S. Luzon & 0.1932 & 0.3978 & 2.2212 & 1.4953 & 3.4803 & 1.0642 \\
\hline Visayas & 0.9479 & 308.3476 & 0.5600 & 5.4110 & 0.4648 & 2.8927 \\
\hline Mindanao & 1.5398 & 2.2275 & 7.7946 & 0.3930 & 2.1717 & 1.8629 \\
\hline TOTAL & 1.2896 & 0.5180 & 1.5411 & 2.0083 & 1.8068 & \\
\hline Avg IO/OD Ratio & 1.0258 & 62.5682 & 2.5105 & 2.1410 & 1.8786 & 1.5346 \\
\hline
\end{tabular}

A side-by- side comparison of freight flow data in monetary terms of JICA-DOTC survey and MRSAM study is now undertaken. (Figures $5 \& 6$ ) Adjustments are made so that metric ton units in JICA-DOTC survey are converted into monetary units in 1994 prices using NSO per peso metric ton conversion rate. This was deemed a better option since the concept of quantity in I-O is different from volume measurement in O$\mathrm{D}$ data. A comparative view of the monetary values from O-D tables (JICA-DOTC survey) and I-O tables (5 regions SAM) is shown in Table 7.

Table 7: Comparison of Commodity Flow Data from I-O and O-D Tables (Million Pesos at 1994 Producer Prices)

\begin{tabular}{|l|r|r|r|r|r|r|}
\hline $\begin{array}{c}\text { Origin/ } \\
\text { Destination } \\
\text { Region }\end{array}$ & I-O Outflows & O-D Outflows & $\begin{array}{c}\text { \% Differential } \\
\text { (IO-OD) }\end{array}$ & I-O Inflows & O-D Inflows & $\begin{array}{c}\text { \% Differential } \\
\text { (IO-OD) }\end{array}$ \\
\hline NCR & 606,720 & 531,450 & 14.2 & 647,896 & 502,388 & 29.0 \\
\hline N. Luzon & 292,491 & 411,028 & -28.8 & 323,094 & 623,717 & -48.2 \\
\hline S. Luzon & 607,394 & 570,752 & 6.4 & 530,852 & 344,466 & 54.1 \\
\hline Visayas & 236,874 & 81,888 & 189.3 & 265,256 & 132,082 & 100.8 \\
\hline Mindanao & 332,225 & 178,335 & 86.3 & 308,605 & 170,800 & 80.7 \\
\hline TOTAL & $2,075,704$ & $1,773,453$ & 17.0 & $2,075,704$ & $1,773,453$ & 17.0 \\
\hline
\end{tabular}




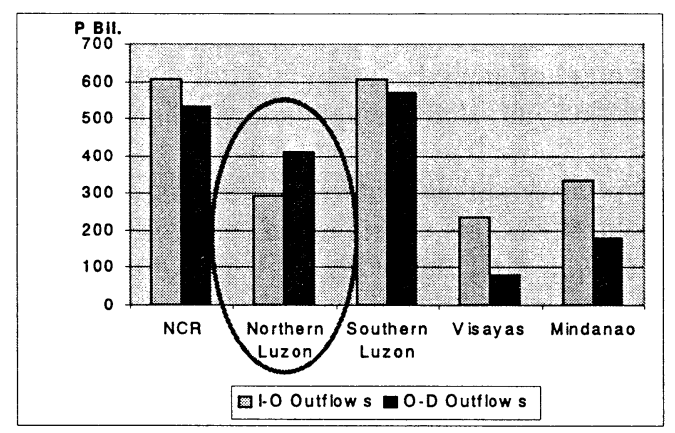

Figure 5. I-O \& O-D Outflow Data

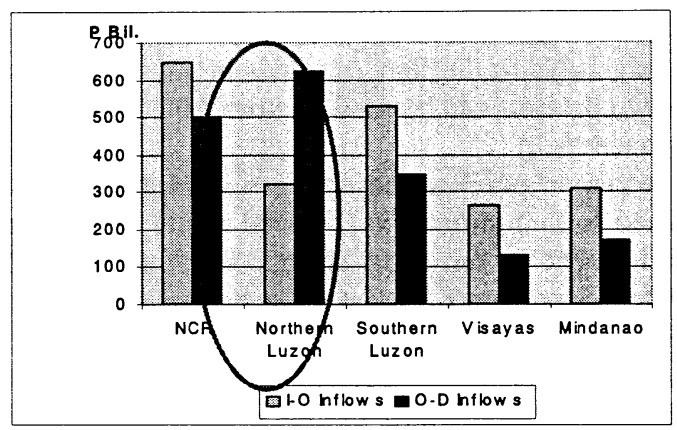

Figure 6. I-O \& O-D Inflow Data

\section{(4) Comparison of Results in Terms of Direction of Freight Flow}

A cell-by-cell comparison of the direction of net commodity flow is undertaken. This is to establish similarity in the direction of movement of commodities in both data sets. Tables 8 shows that the direction of flow of goods is the same for all O-D and I-O pairs with some exceptions. The exception is for commodity flows emanating from Visayas to Northern Luzon and then from Northern Luzon to Visayas. The reason for this discrepancy lies in the number of location sites in Visayas and N. Luzon chosen in JICA-DOTC O-D Survey. (See Figures $7 \& 8$ ). The criteria used for number of location sites per region was strategic location in transport routes. This resulted in more sites chosen in Visayas and Northern Luzon.

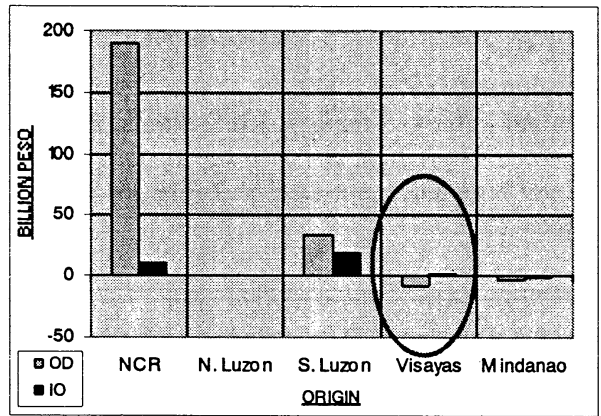

Figure 7. Net Outflow of Goods - NOL Destination

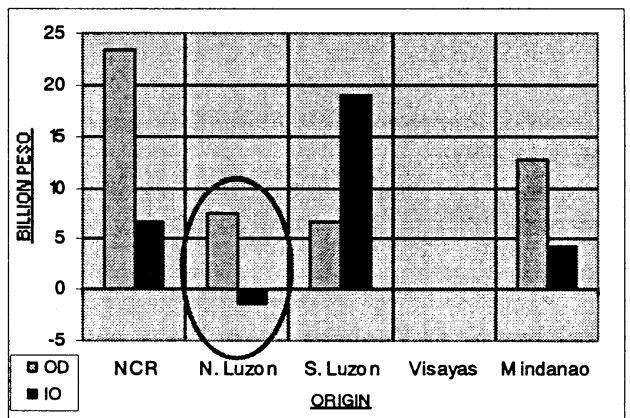

Figure 8. Net Outflow of Goods- VIS Destination

Table 8: Net Outflow of Goods - JICA-DOTC Commodity Flow Survey (Million Pesos, in 1994 prices, Outflow- Inflow of Goods = Net Outflow)

\begin{tabular}{|c|c|c|c|c|c|c|}
\hline \multirow[t]{2}{*}{ Origin } & \multicolumn{6}{|c|}{ Destination } \\
\hline & NCR & N. Luzon & S. Luzon & Visayas & Mindanao & TOTAL \\
\hline NCR & 0 & 189,259 & $-180,663$ & 23,295 & $-2,828$ & 29,063 \\
\hline N. Luzon & $-189,259$ & 0 & $-34,008$ & 7,455 & 3,122 & $-212,689$ \\
\hline S. Luzon & 180,663 & 34,008 & 0 & 6,697 & 4,917 & 226,286 \\
\hline Visayas & $-23,295$ & $-7,455$ & $-6,697$ & 0 & $-12,746$ & $-50,194$ \\
\hline Mindanao & 2,828 & $-3,122$ & $-4,917$ & 12,746 & 0 & 7,534 \\
\hline TOTAL & $-29,062$ & 212,689 & $-226,286$ & 50,194 & $-7,535$ & \\
\hline
\end{tabular}

\section{Conclusion}

The above results indicate that there is a way of enriching the database for SCGE modeling in a developing country like the Philippines. It can be done by linking freight flows from O-D tables of surveys and interregional commodity flows of I-O table contained in MRSAM. There can be complementarities between primary and secondary data sources. Reconciliation and balancing of results can be implemented if control totals can be derived from primary data sources. Secondary sources like those from government statistical agencies can be used to balance and adjust cell entries in O-D and I-O data. A simple methodology was devised, utilizing variable database from both I-O and O-D tables, so that interregional flows of goods can be comprehensively estimated. The I-O data which were separately estimated can provide the complete 
monetary value of transporting a good from producer to consumer. Whereas, O-D data can provide idea of the magnitude of the flow of goods in physical units from point of embarkation to point of disembarkation. The two datasets can be used as cross -checks as far as direction and relative magnitude of commodity flows are concerned.

A common point which emerges from all these is that primary survey of O-D flows must be carefully planned so that information derived meets the research's objective. This covers a wide array of factors like improvement in sampling design, adopting an optimal sample size, achieving high response rate from targeted respondents by lessening respondent burden and assuring confidentiality of response and tapping state-of -the art technology in administering survey questionnaires within a given budget. If transport survey methods can be streamlined further so that O-D flows in physical units complement I-O flows in monetary units, then both the transportation planner and economic planner will have a rich database to work on. With this initial effort in reconciliation, revalidation and integration, SCGE modeling will no longer be an unexplored frontier in transportation planning and economic planning in a developing country like the Philippines.

\section{References}

1) Japan International Cooperation Agency (JICA) - Dept. of Transportation \& Communication (DOTC): The InterRegional Passenger and Freight Flow Surveys in the Republic of the Philippines - Final Report, Dec. 2004.

2) Bureau of Agricultural Statistics: Cost \& Returns Survey for Agricultural Products- 2002.

3) Department of Finance: Annual Financial Statistics. 1995.

4) Gunn, Hugh. SCGE Models: Relevance \& Accessibility for Use in the UK, with emphasis on Implications for Evaluation of Transport Investments. August, 2004.

5) National Statistics Office: 1994 Family Income \& Expenditure Survey, Manila.

6) National Statistics Office: 1994 Census of Establishments, Manila.

7) National Statistical Coordination Board: 1994 Philippine Input-Output Tables. 1999.

8) Secretario, Francisco: 1994 Philippines Interregional Input-Output Table - 5 regions. JSPS-Manila Project, Manila Database. 2002.

9) Secretario, F. "Phase III Construction of a Multi-region Inter-regional Input-Output Table for the Philippine Economy, 1994 “- JSPS -Manila. Input-Output Research Project. 2002

\section{Reconciling O-D Freight Flow Data and Interregional I-O/Multi-Regional SAM Data for SCGE Database in a Developing Country*}

\section{By Cristela Goce-DAKILA**\& Shoshi MIZOKAMI***}

Impact assessment of transport infrastructure investment on regional economic welfare usually utilizes an SCGE model. The creation of a database for such modeling exercise in developing countries like the Philippines imposes a challenge to researchers due to lack of data. This paper addresses such concern by reconciling primary survey freight flow data gathered by JICA-DOTC team and secondary interregional input-output data from five-region social accounting matrix constructed by authors for the Philippines. Ultimately, the dataset will provide concrete benchmarks for testing the empirical validity of SCGE models with a transport sector.

\section{途上国における地域間純流動調査による OD データと地域間 IO データとの整合性の検討}

\section{Cristela Goce-DAKILA**, 溝上章志***}

地域経済における交通基盤整備のインパクトを評価するのに SCGE モデルが活用される．しかし，途 上国では各種の統計データの未整備のためにキャリブレーション用のデータベースの作成は非常に困難 となっている. 本研究では, JICA-DOTC プロジェクトによって実施された 1 次データである地域間物 流・人流純流動調査データと独自に作成した 2 次データである 5 地域 SAM の中の地域間 IO データとの 整合性について検討を行った. その結果, 純流動調査デー夕は輸送部門を含む SCGE モデルの有効性を 実証的に検証するためのベンチマークを提供することが示された. 